\title{
Framing Analysis of Islamic Marriage Sermon in Perspective of Gender Equality
}

\author{
Diyah Utami ${ }^{\bowtie}$, Ali Imron, Refti Handini \\ Sociology Department of Surabaya State University, Indonesia
}

Permalink/DOI: http://dx.doi.org/10.15294/komunitas.v6i2.3311

Received : July 2014; Accepted: August 2014; Published: September 2014

\section{Abstract}

Knowledge of gender in the context of marriage sermon is closely related to the interpretation of religious doctrines concerning the relationship of men and women. This study aims to understand the perspective of gender equality on Islamic marriage sermon through framing analysis. This study used framing analysis to reveals the frame of a text by using framing devices that are directly related to the central idea of the text and reasoning. The devices are associated with the cohesion and coherence of the text that refer to a particular idea of marriage. Islamic sermons such as text still tend to show discriminatory for example, this can be felt in the reproduction of a sentences like this: such as sentence "the ideal family is where the husband and wife make a living for their household, especially by giving love and education to children". The word "ideal" or "good" is a framing device. And the phrase, "if the wife works outside the home, the family will lose orientation". The word "disoriented" indicates that family whose wife works outside of the house is a failed family. In this case, the wife is used as a scapegoat for the failure of a family as a wife who works outside.
\end{abstract}

\begin{abstract}
Abstrak
Pengetahuan tentang gender dalam konteks pernikahan khotbah berkaitan erat dengan penafsiran doktrin agama tentang hubungan pria dan wanita. Penelitian ini bertujuan untuk memahami perspektif kesetaraan gender dalam khotbah perkawinan Islam dalam analisis perspektif framing. Penelitian ini menggunakan analisis yang mengungkapkan bingkai teks dengan menggunakan perangkat framing yang langsung berhubungan dengan gagasan utama dari teks dan penalaran framing. Perangkat yang terkait dengan kohesi dan koherensi teks yang merujuk pada ide tertentu pernikahan khotbah Islam Teks masih cenderung menunjukkan tindakan diskriminatif, seperti kalimat "keluarga yang ideal adalah di mana suami dan istri mencari nafkah untuk keluarga mereka, terutama dengan memberikan cinta dan pendidikan untuk anak-anak. Kata "ideal" atau "baik" adalah perangkat framing. Dan kalimat, "jika istri bekerja di luar rumah, keluarga akan kehilangan orientasi”. Kata "bingung" menunjukkan bahwa keluarga yang istrinya bekerja di luar rumah adalah keluarga yang gagal. Dalam hal ini, istri digunakan sebagai kambing hitam atas kegagalan keluarga sebagai istri yang bekerja di luar.
\end{abstract}

Keywords: framing analysis; gender equality; islam; marriage sermon

How to Cite: Utami, D., Imron, A. \& Handini, R. 2014. Framing Analysis of Islamic Marriage Sermon in Perspective of Gender Equality. Jurnal Komunitas, 6 (2): 320-326. doi: 10.15294/komunitas.v6i2.3311

(C) 2014 Semarang State University. All rights reserved

\footnotetext{
Corresponding author :

Jalan Ketintang, Surabaya 60231, Phone. (031) 8280009

E-mail: diviyava@yahoo.com
} 


\section{INTRODUCTION}

Discussion of the relationship between men and women in the context of social science leads to the concept of gender. Women's Studies Encyclopedia defines gender as a cultural concept, seeks to make a distinction in terms of roles, behavior, mentality, and emotional characteristics between men and women who thrive in a society (Mufidah, 2004). The embodiment of these gender differences are women perceived as more emotional, delicate, painstaking, and a number of other feminine characteristics. Otherwise, men are considered to have a more rational and assertive characteristics. If there are women and men who have opposite or contrary characteristics of what is determined by the community, it can be regarded as an unusual thing, even deviation. Determination of the nature of the differences eventually leads to the determination of the different roles. The emergence of balanced gender relations between men and women is due to the strong culture of patriarchy that causes inequality or injustice on gender relations.

Gender inequality manifests itself in various forms of injustice, namely marginalization or economic impoverishment, subordinated or not important assumption in political decisions, steorotype forming (negative labeling) and violence. Research shows that violence against women is a very big problem. Violence has put women at risk of short-term and long term consequences involving psychological, physical, economic and social welfare (King'ori, Odera, and Oboka, 2014: 14). Gender inequality also raises another reality on a longer and more workload (double burden) and ideology socialization of gender values (Fakih, 2004). Some researches indicate that gender inequalities which cause double burden for women not only in the domestic sector but also in the public sector. That conditions lead to social relations between men and women which has not been balanced yet (Luthfi, 2010: 83)

There are two mainstreams to understand gender, among others, nature theory and nurture theory. The nature theory assumes that the biological nature between men and women are different. The physical nature differences have effect on the condition of each human (Budiman, 1996). Women with physical nature to bear have the consequences in the development of psychological temperament needed to care for children who are born, such as maternal temperament that require delicate attitude, patient, and affection. Men. with their physical nature of having the penis and sperm production with physical and psychological nature, are constructed for hard sector, while providing protection to the weaker, women. The differences between the two biological characteristics in both have result in the psychological temperament.

Nurture theory does not agree that the selection of the position and the roles of men and women are the nature characteristics. Biological factors do not cause the superiority of men over women, segregation and superiority of men due to cultural elaboration of the respective biological (Budiman, 1996). Thus what is called with masculine and feminine characteristics are the result of the culture. Cultural theory with materialist perspective, the superiority of men over women as constructed by the culture with communal objects ownership shift into private property. The understanding of the two genders perspective also raises different understandings of gender relations. The emergence of unbalanced gender relations can not be separated from social institutions, whose function is to provide outreach to members of the public about gender values. Social institutions referred to in this case is a family institution, education or religion (Dewi, 2006: 8-10).

This research article uses Gramsci's central concept of hegemony. The starting point of Gramsci's concept of hegemony is that a class and its members exercise the power toward the below classes by force and persuasion (Simon, 1999). Furthermore Gramsci develops the idea of leadership and its implementation as a condition for obtaining state power into the concept of hegemony. Hegemony is a relationship between classes with other social forces. Hegemony class group is a class which gets approval 
from powerful authority and other social classes by creating and maintaining a system of alliances through political and ideological struggle.

One of the important issues in the concept of hegemony is the importance of language in establishing intellectual leadership and moral. This is not because the language itself is something which maintains hegemonic function. Gramsci (in Bagong 2010) writes, "... every language contains the elements of the world", which means that mental activity will depend on the character of the vocabulary availability in the language.

The formation of different discourses between men and women is a form of hegemonic language. Discourse is a study in the application of postmodernism theories of the struggle between authority and knowledge in the context of social relations among the community members (Yunindyawati, et al, 2014: 171). The discourse between authority and knowledge is what leads construction on social reality, including the reality of putting the position of men and women in society. In this discourse, women are constructed by the dominant ideology as a class or group that is controlled, while the men are the dominant class. As confirmed by the feminist theories, social construction does not only distinguish women with men on gender (gender differences), but also forms the ideology of gender inequality (gender inequality) and even gender oppression (in Bagong, 2010). "Women" is a class (women as a class) who is under the influence of hegemony by cultural structures of patriarchy which gives certain privileges to men. Cleric as a religious authority has the power to infuse gender ideology in the marriage relationship. Accordingly, it is important for this study to use Gramsci's hegemony theory.

One media which can be used as a means of socialization of gender ideology to the general public is a marriage sermon. Knowledge of gender in the context of marriage sermon is closely related to the interpretation of religious doctrines about the relationship of men and women. This article be- comes interesting for several reasons. First is to see whether or not the change of gender equality awareness among modern theologians exists. Second is as an attempt to assess gender construction among theologians not only can be done through the interview process, but could also be done through the study of material marriage sermon delivered by scholars or the speaker. Marriage sermon material is actually a reflection of the understanding of theologians about the meaning of gender which is tried to socially interact with other people. This article will analyze the Islamic marriage sermon using framing approach with the aim to understand the perspectives of gender equality in Islamic marriage sermon.

\section{METHODS}

This research used framing analysis, an analysis which revealed the frame of a text of William A. Gamson and Andre Modigliani. This research raised the concept of the frame as a perspective that ultimately determined what the facts were taken, which parts were highlighted and removed, and was about to carry the news. This research took place at the Cheng Ho Mosque, located in Jalan Gading, Ketabang, Genteng, Surabaya and National Mosque Al Akbar located at Jalan Masjid Al Akbar Timur No. 1 Surabaya.

The data collection was done by recording and noting the marriage sermon text which are held in the mosques that had been predetermined. The recording lasted for two months, started on 23 August to 23 October 2013. After the data was collected and analyzed using framing, an analysis which revealed the frame of a text. The frame in a text was determined by the package. The existence of the package was visible from the central idea that was supported by the discourse (words, sentences, images, graphics, and etc). All of these elements led to certain ideas and supported the central idea of a text. There were two devices to translate the central idea of a text. First was the framing device. The device was directly related to the central idea that was emphasized in the text. Framing device was characterized by the use of words, sentences, images / graphics, and 
certain metaphors. Second was reasoning devices. The device associated with the cohesion and coherence of the text which refered to a particular idea. This research analyzed the elements of the framing in a sermon material.

The following table provides more detailed explanation about the flow of data analysis.

\section{RESULTS AND DISCUSSION}

A discussion of the Islamic marriage sermon text will be more interesting when the approach uses a framing analysis. The analysis is chosen because Islamic values which are associated with social roles relations between husband and wife still have the values containing gender bias. The values containing gender bias leads to the tendency to take side on one of gender orientations (male or husband) and creating the discrimination to another orientation (woman or wife). The form of taking side and discriminatory on one to another can be seen from the text of marriage sermon which is delivered by an Ustadz who leads the process of the marriage ceremony (Naib).

Through the framing analysis, how text constructs the reality can be investigated. An event can be understood not because it is justified, but there are actors who are able to construct such reality of the event. In the context of Islamic marriage sermon, the actor is an Ustadz who delivers the sermon or lecture. Ustadz is considered to have an extensive knowledge associated with Islamic values, including Islamic ethics in social relations between husband and wife. Through this scientific capacity, Ustadz is able to construct the reality of family relations between husband and wife. Therefore, through framing analysis, the central point is on how the Ustadz constructs events in particular circumstances. The framing constructed by the Ustadz is used to provide an assessment of the event (in this case about a family that sakinah, mawaddah, warohmah or harmonious family). This study specifically describes and analyzes the text of the sermon on the power of the Islamic marriage constructed by Ustadz in the review of framing analysis.

Based on the data which was collected in this study, the discussion of the text will be analyzed on one sermon text only. The sermon text is delivered by Prof. Moh. Rumrowy focusing on the discussion of the future education for children in a family. The ustadz who is also an alumnus of the University of Al-Azhar, Cairo, Egypt states that children education for both physical and spiritual needs is very important. However, spiritual education must be regarded as the moral foundation of the child in the future life. Education for children starts from the family and parents should be responsible

Table 1. Framing Gamson dan Modigliani Device (Eriyanto, 2007)

\section{Frame}

Central organizing idea for makingsense of ant events, suggesting what is at issues

\begin{tabular}{ll}
\hline \hline Frame Devices & Reasoning Devices \\
\hline Methapors & Roots \\
parable or supposition. & Causal analysis or cause and effect. \\
\hline \hline
\end{tabular}

\section{Catchphrases}

Interesting phrase, contrast, stand out in a discourse. It is generally in the form of jar-

\section{Appeals to principle}

Basic premise, moral claims gon or slogan.

\section{Exemplaar}

Uniting the frame with an example, the description (could be theory, comparison) which clarifies the frame

\section{Consequences}

Effect or consequences which is obtained from the frame. 
Table 2. The Analysis of Islamic Marriage Sermon Text by Gamson and Modigliani

FRAME

Frame Devices

Words and phrases which are discriminatory

"a wife is forbidden to go against her husband"

Sentence which indicates domestification of social roles in a family.

"The ideal family is a family where the husband works for a living and his wife runs the household."

\begin{tabular}{ll}
\hline $\begin{array}{l}\text { Methapors } \\
\text { Parable or supposition }\end{array}$ & $\begin{array}{l}\text { Roots } \\
\text { Causal analysis or cause and effect }\end{array}$ \\
\hline "a wife is a husbnad's significant other" & $\begin{array}{l}\text { If a wife will go outside but there is no per- } \\
\text { mission from the husband, then she will be } \\
\text { condemned by God. }\end{array}$ \\
\hline
\end{tabular}

\section{Catchphrases}

Interesting phrase, contrast, stand out in a discourse. It is generally in the form of jargon or slogan.

A wife is a gracious creature

\section{Reasoning Devices}

Hadith of Shoheh Bukhori Muslim:

"A wife has the responsibility to ask permission to her husband if she will go outside".

Cohesion and coherence of the text which refers to an idea that "it is forbidden for a wife leaving their house without any permission from her husband."

"A wife has the responsibility to take care of the household, including the responsibilty to provide affection and education to the children."

\section{Appeals to principle}

Basic premise, moral claims

Hadith Shoheh Bukhori Muslim:

Women in Javanese slogan:

"Wani ditoto" (women must be willing to be regulated and controlled)

"a wife's bussiness is a husband's bussiness, a wife is obliged to ask for permission from their husband before they go out of the house"

"If there is a wife who works outside, the familly will lose the orientation of the family"

Family whose wife works outside the house is cosiderd as a failed family. A wife is considered as a causal of failure.

\section{Exemplaar}

Connecting the frame with an example, the description (could be theory, comparison) which clarifies the frame.

\section{Consequences}

Effect or consequences which is obtained from the frame.

A tale of Noah's wife who is not obedient Women or wives become very cornered, to her husband then she gets punishment. the space is very limited. 
for the educational success of children. According to him, "a wife who works outside is not a good wife and it does not reflect a good family as well".

The text can be connected with the previous text. The previous text explains the main task of the wife which is to guide and educate their children in the family; it means that the area or space for the wife is just limited to the domestic area (household) only. This text is positively correlated with the second text which states that a wife who works outside of the house is referred to as a "not ideal" family.

The next text tries to make reasoning devices. The device is associated with the cohesion and coherence of the text which refers to a particular idea; an ideal wife only handles the domestic area (household) only. Even the Ustadz conveys his claim especially by saying the following sentence:

If there is a wife who works outside the house, the family will loss the orientation in that family. The orientation is just purely economic needs.

The word "disoriented" indicates that the family whose wife works outside the house is a family who fail in fostering their household. In this case, the wife will be used as a scapegoat of the failure in a family because the wife works outside the house. Even, if the juvenile delinquencies are usually uassociated with the failure of the wife or mother in guiding and educating their children. Because the wives who work in the domestic sector, the deviations committed by the children are always blamed to the mother or wife as the main actor because they are in the house. Through the following table, it will be obtained a description of the frames in Islamic marriage sermon text in accordance with the framing concept of William A. Gamson and Andre Modigliani.

\section{CONCLUSION}

Islamic marriage sermon text still tends to discriminatory to women and has not shown any indication of gender equality. Through framing analysis, the constructed frame in the text consists of a framing device. Sermon text still contains some discrimination elements, as in the phrase "the ideal family, where the husbands go to work and wives run the household, especially in giving love and education to the children". The sentence indicates that domestication occurred in the social role of the family. The words "ideal family" indicates that a good family is a family that can meet the above requirements.

The word "ideal" or "good" is the framing device. While the phrase, "if the wife works outside the house, the family will lose the orientation of the family". The word "disoriented", indicates that the family whose wife works outside the house is a failed family. In this case, the wife is used as a scapegoat for the failure in a family because as a wife who works outside the house. Even, the current juvenile delinquencies are claimed to be the failure of the wife or mother in guiding and educating their children. Because the wives who work in the domestic sector, the irregularities committed by the children are always charged to the mother or wife as the main actor who is in the house.

\section{ACKNOWLEDGEMENT}

Thank you to the management of DIPA Surabaya State University in 2013 who provided the fund for this research.

\section{REFERENCES}

Budiman, A. 1996. Menggugat Partriarkhi. Yogyakarta: Bentang Budaya.

Dewi, S. R. 2006. Gender Mainstreaming: Feminisme, Gender, dan Transformasi Institusi. Jurnal Perempuan. 50: 1-16.

Eriyanto. 2007. Analisis Framing: Konstruksi Ideologi, dan Politik Media. Yogyakarta: LKis.

Fakih, M. 2004. Analisis Gender E Transformasi Sosial. Yogjakarta: Pustaka Pelajar.

King'ori, O. and Oboka. 2014. Gender Difference in Traumatic Experiences and Level of Post Traumatic Stress Disorder among Children Survivors in Areas Affected by the Post-Election of 2007/2008 in Nakura County, Kenya. Research on Humanities and Social Sciences Journal. 4 (15): 14-20.

Luthfi, A. 2010. Akses dan Kontrol Perempuan Petani Penggarap Pada Lahan Pertanian PTPN IX Kebun Merbuh. Jurnal Komunitas; Research E Learning in Sociology and Anthropology. 2(2): $74-83$.

Mufidah. 2004. Paradigma Gender. Malang: Bayume- 
dia Publising.

Simon, R. 1999. Gagasan-Gagasan Politik Antonio Gramsci. Yogyakarta: Pustaka Pelajar.

Suyanto, B. \& M. Khusna A. (eds.). 2010. Anatomi dan Perkembangan Teori Sosial. Malang: Aditya Media Publishing.
Yunindyawati, dkk. 2014. Kontestasi Diskursus Ketahanan Pangan dan Pembentukan Kuasa Pengetahuan Perempuan Pada Keluarga Petani Sawah di Sumatera Selatan. Jurnal Komunitas: Research \& Learning in Sociology and Anthropology. 6 (1): 170-179. 